\title{
Disclosure Quality and Corporate Governance: Evidence from Iran
}

\author{
Fatemeh Soheilyfar \\ Accounting Department, Dezful Branch, Islamic Azad University, Dezful, Iran \\ E-mail: nasimsoheilyfar@yahoo.com \\ Mohammad Tamimi \\ Accounting Department, Dezful Branch, Islamic Azad University, Dezful, Iran \\ E-mail: tamimi.mohammad@gmail.com \\ Mohammad Ramezan Ahmadi \\ Accounting Department, Shahid Chamran University, Ahvaz, Iran \\ E-mail: ahmadi-m@scu.ac.ir \\ Nasrollah Takhtaei (Corresponding author) \\ Accounting Department, Dezful Branch, Islamic Azad University, Dezful, Iran \\ E-mail: nasrollah_takhtaei@yahoo.com
}

Received: July 20, 2014 Accepted: August 13, 2014 Published: December 1, 2014

doi:10.5296/ajfa.v6i2.6000 URL: http://dx.doi.org/10.5296/ajfa.v6i2.6000

\begin{abstract}
This study explores the relationship between disclosure quality and corporate governance in Tehran stock exchange (TSE). In this study, the mechanisms of corporate governance are consist of internal audit, ownership concentration, CEO duality, board independence, board size, board chairman independence, and chairman tenure. On the other hand, the measure of disclosure quality calculated by the Stock Exchange Organization (SEO) has been used as a proxy for disclosure quality. Using a sample of 83 accepted firms on Tehran Stock Exchange (TSE) over the period from 2005 to 2010, the results reveal that there is a significant and positive relationship disclosure quality and each of independent variables such as internal audit, ownership concentration, CEO duality, board independence, and chairman independence, but no association between disclosure quality and each of board size and chairman tenure.
\end{abstract}

Keywords: Disclosure Quality, Corporate Governance, Informational Asymmetry 


\section{Introduction}

Considering the process of the disclosure of the information, the investors deal with informational asymmetry. This problem arises when one of the two parties to a deal has more information than the other (Graham, Koski, \& Loewenstein, 2006). The role of the responsible individuals of the information disclosure is indicated in the corporate governance which includes monitoring and the procedures to make sure that not only the firm management does not have incentive to make their own profits but also they attempt to increase the interests of the investors and the firm value (Kanagaretnam, Lobo, \& Whalen, 2007). The appropriate application of the corporate governance mechanisms is a basic step to use optimum resources, increasing the responsibility, transparency, regarding the justice and the rights of the parties who have interests in the firm (Jalali, 2008). The high level of disclosure quality is useful for the firm because it has the potential to decrease the cost of capital (Botosan, 1997; Diamond \& Verrecchia, 1991; Lev, 1992), meaning that it may lead to decreasing the expense of the debt (Sengupta, 1998) and increasing the stock price (Healy, Hutton, \& Palepu, 1999; Lang \& Lundholm, 2000; Welker, 1995). However, if the given information by the managers is not completed, the firms will not get all of the advantages. Considering the motivations of managing for information disclosure, it is possible that the information disclosure be distorted (Donnelly \& Mulcahy, 2008). The low level of information disclosure causes inappropriate allocation of the resources in the stock market, since it causes that the investors make economic decisions based on wrong information (Cerbioni \& Parbonetti, 2007). The current study investigates if the corporate governance mechanisms influence on the information disclosure quality.

\section{Literature Review}

Klein (1998) investigates about the role of the non-independent directors and independent directors, in undertaking the duties of the decision management and decision control, and she required some documents in the case of the value of the presence of non-independent directors in control committees such as the audit committee and supervisory committee to the financial reporting quality (Nikoomaram \& Badavar Nahandi, 2009). Lakhal (2005) examines the relationship between the voluntary disclosure of the French firms' managers and the mechanisms of corporate governance. The results show that if the ownership structure is pretty dispersed and has more non-independent managers on board, the level of voluntary disclosure will be increased. The duality in managing director's duties will probably decrease the level of the voluntary disclosure of the information. There is a small relationship among the number of the board independent members and making decision about voluntary disclosure and board size and voluntary disclosure. The results of the research indicate a negative relationship between board size and voluntary disclosure which is not what they expected. The relationship between the firm characteristics, the corporate governance rules and the level of voluntary disclosure in Spain was explored by Babío Arcay and Muiño Vázquez (2005). The results of the study show that the ratio of independent directors on the board of directors, the existence of the audit committee in the firm and the cooperation of the board of directors in the firm investment and also offering the stock option plans to the managers as the fee, are related to the disclosure. Cheng and Courtenay (2006) analyze the 
relationship between the ratio of independent directors on the board of directors, the board size and also the duality of the managing director's duties with voluntary disclosure. The results indicate that the ratio of the independent directors is directly related to the level of voluntary disclosure and also the board size and the duality of the managing director's duties are not related to the voluntary disclosure. Akhtaruddin, Hossain, Hossain, and Yao (2009) investigate the relationship between corporate governance and voluntary disclosure of information in annual reports. The results demonstrate that there is a positive association between the board size and the voluntary disclosure of the information and also between the number of the independent managers and voluntary disclosure of information. Nevertheless, the level of the voluntary disclosure has a negative relationship with family control, but there is no relationship between the ratio of the audit committee members to total number of directors on the board and voluntary disclosure of information.

Sajadi, Zaranejad, and Jafari (2009) investigate the non-financial characteristics effectiveness to the quality of the financial reporting in accepted firms on Tehran Stock Exchange. The results reveal that the size of the firm, the age of the firm and the type of the industry have a positive and significant relationship and the ownership structure has a negative relationship with the financial reporting quality, but type of audit firm is not significantly associated with financial reporting quality. Khodadadi, Khazami, and Aflatooni (2010) explore "the effect of corporate governance structure on the extent of voluntary disclosure in Iran". In their study, the corporate governance mechanisms were the ratio of the independent directors on the board of directors, the percentage of the institutional investors and the duality of the managing director and the chairman of board of directors' duties. Using a sample of 106 accepted firms on Tehran Stock Exchange (TSE) during period from 2001 to 2005, the results indicate that there is a significant relationship between the ratio of the independent directors and duality in the managing director's duties with the level of voluntary disclosure. In addition, the results document a significant association between the percentage of the institutional investors and the level of voluntary disclosure of information. Using a sample of accepted firms on Tehran Stock Exchange over the period from 2002 to 2009, Khoshbakht and Mohammadzadeh Salteh (2011) investigate the relationship between the corporate governance mechanisms and the discretionary disclosure of information. In their study, the corporate governance mechanisms include the percentage of the board independent members, the ownership concentration, institutional ownership, free floating stocks and the type of the firm auditor. The results reveal that the relationship between the percentage of the independent directors on board and institutional ownership with the level of the discretionary disclosure of information in the firms is significant, but they report no significant relationship between three mechanisms of the corporate governance such as ownership concentration, free floating stocks and the type of the firm auditor and the level of the discretionary disclosure of information.

Aburaya (2012) examines the relationship between the corporate governance and the environmental disclosure quality of the firm. The results designate that there is significant association between the environmental disclosure quality of the big firms and the mechanisms of corporate governance. The results also report a negative and association 


\section{Macrothink Institute ${ }^{\mathrm{TM}}$}

between CEO duality and environmental disclosure quality, indicating that holding position of the managing director and board chairman by the same person reduce environmental disclosure quality, but a positive and significant association board meetings and environmental disclosure quality, suggesting that the more the number of board meetings, the more the quality of environmental disclosure. In a similar way, Katmun (2012) investigates the effective factors on disclosure quality. The results show that there is a significant positive relationship between each of audit committee, number of board meetings, board independence and disclosure quality.

\subsection{Research Hypotheses}

According to the abovementioned literature, seven hypotheses are developed as follows:

H1: there is a significant relationship between internal audit unit and disclosure quality.

H2: there is a significant relationship between ownership concentration and disclosure quality.

H3: there is a significant relationship between CEO duality and disclosure quality.

H4: there is a significant relationship between board independence and disclosure quality.

H5: there is a significant relationship between board size and disclosure quality.

H6: there is a significant relationship between board chairman independence and disclosure quality.

H7: there is a significant relationship between chairman tenure and disclosure quality.

\section{Research Methodology}

This research is a type of correlational and regression analysis and hence will investigate the correlation between dependent variable and independent variables. Since the data are of cross-section and time-series type, the panel data models (fixed or random effects) are used to test the hypotheses.

\subsection{Sample Selection and Data Sources}

The sample consists of 83 accepted firms on the Tehran Stock Exchange (TSE) during the period from 2005 to 2010 (5 fiscal years), and accordingly 498 firm-year observations are used. Data required to test the hypotheses are collected using data sources such as compact disks (CDs) issued by Tehran Stock Exchange Organization, TadbirPardaz database and other sites of Stock Exchange Organization.

\subsection{Variables Definition}

\subsubsection{Measuring Dependent Variable}

1. Disclosure quality (DQ) is the dependent variable in this study. To measure this variable, the annual report under title "ranking firms by disclosure quality score" is employed in which each firm is given a score by Tehran Stock Exchange Organization (TSEO) annually. 


\subsubsection{Measuring Independent Variables}

1. Internal audit (IA): to measure this variable, a dummy variable is used where internal audit (IA) set to "1" if firm has internal audit unit and zero "0" otherwise.

2. Ownership concentration (OWNCON): Ownership concentration is measured as the ratio of common shares owned by concentrated shareholders over total shares outstanding by firms.

3. CEO duality (CEOD): A dummy variable is used to measure the CEO duality where CEO duality equals "1" if chief executive director is not board chairman and zero "0" otherwise.

4. Board independence (BODIND): this variable is measured as the number of independent directors on board divided by total number of board of directors.

5. Board size (BODS): board size is defined as the number of total number of board of directors who may be independent or non-independent directors.

6. Board chairman independence (BODCI): board chairman independence (BODCI) is measured by a dummy variable where board chairman independence (BODCI) set to " 1 " if the chairman of the board is a non-executive director and zero " 0 " otherwise.

7. Chairman tenure (CHAIRTEN): chairman tenure is measured as the number of years the chairman had held that position in a given firm.

\subsubsection{Measuring Control Variables}

1. Financial leverage (LEV): financial leverage as a control variable is measured as the total debts liabilities over total assets.

2. Firm size (FSIZE): firm size is the control variable which is measured by the natural logarithm of total assets of the firm at the end of the fiscal year.

\subsection{Model Specification}

$$
\begin{aligned}
D Q= & \beta_{1}+\beta_{2}(I A)+\beta_{3}(\text { OWNCON })+\beta_{4}(C E O D)+\beta_{5}(\text { BODIND })+\beta_{6}(B O D S) \\
& +\beta_{7}(B O D C I)+\beta_{8}(C H A I R T E N)+\beta_{9}(L E V)+\beta_{10}(\text { FSIZE })+\varepsilon
\end{aligned}
$$

Where:

$$
\begin{aligned}
& D Q=\text { Disclosure quality } \\
& I A U=\text { Internal audit } \\
& O W N C O N=\text { Ownership concentration } \\
& C E O D=\text { CEO duality } \\
& B O D I N D=\text { Board independence } \\
& B O D S=\text { Board size } \\
& B O D C I=\text { Board chairman independence } \\
& C H A I R T E N=\text { Chairman tenure } \\
& L E V=\text { Financial leverage }
\end{aligned}
$$


$F S I Z E=$ Firm size

\section{Empirical Results}

\subsection{Descriptive Statistics}

Usually the most useful and first step in organizing data is ordering data based on a logical criterion and then acquiring the central indexes and distribution. Totally, by appropriate using of descriptive (statistics) methods, the characteristics of one group of the information can be expressed exactly. Descriptive statistics is always used for determining and expressing the characteristics of research information. Therefore, in this section descriptive statistics of variables in research will be investigated, which is presented in table 1 . The numbers present a general statue of the research data distribution.

The most significant central index is mean which indicates the balance point and the center of distribution and also is a good index to show the centrality of the data. Median is another central index which shows the statue of population. In general, distribution parameters are criteria to determine the level of distribution of each other or distribution to the mean. The range indicates the range of the largest number and smallest number. One of the most important distribution parameters is standard deviation. Among the research variables, ownership concentration and board tenure has the highest and the lowest distribution respectively. The level of asymmetry of the frequency graph is called skewness. If skewness coefficient is 0 , the population will completely be symmetric and if the coefficient is positive, skewness will be towards the right side and if the coefficient is negative, skewness will be towards the left side of the graph. The size of the firm has the most asymmetry and disclosure quality has the less asymmetry to the normal distribution.

Table 1. Descriptive Statistics

\begin{tabular}{|c|c|c|c|c|c|c|c|c|c|c|}
\hline Variables & $D Q$ & $I A U$ & OWNCON & CEOD & BODIND & $B O D S$ & $B O D C I$ & CHAIRTEN & $L E V$ & FSIZE \\
\hline \multirow[t]{2}{*}{ Mean } & & & 0.436 & & 0.61 & & 0.77 & 3.71 & & \\
\hline & 50.10 & 0.55 & & 0.85 & & 5.18 & & & 0.73 & 5.86 \\
\hline \multirow[t]{2}{*}{ Median } & 50 & & 0.41 & & 0.60 & & 1.00 & 2.00 & & \\
\hline & & 1.00 & & 1.00 & & 5.00 & & & 0.77 & 5.80 \\
\hline \multirow[t]{2}{*}{ Maximum } & 98 & & 0.89 & & 1.00 & 10.00 & 1.00 & 20.00 & & \\
\hline & & 1.00 & & 1.00 & & & & & 3.33 & 8.64 \\
\hline \multirow[t]{2}{*}{ Minimum } & -13 & & 0.12 & & 0.00 & & 0.00 & 1.00 & & \\
\hline & & 0.00 & & 0.00 & & 3.00 & & & 0.01 & 2.80 \\
\hline \multirow[t]{2}{*}{ St.Dev } & 25.9 & & 0.19 & & 0.22 & & 0.49 & 3.78 & & \\
\hline & & 0.497 & & 0.36 & & 0.62 & & & 0.29 & 0.65 \\
\hline \multirow[t]{2}{*}{ Skewness } & & -0.22 & 0.38 & -1.84 & -0.39 & & -1.30 & 2.09 & & \\
\hline & -0.16 & & & & & 3.16 & & & 1.72 & 0.42 \\
\hline Observations & 498 & 498 & 498 & 498 & 498 & 498 & 498 & 498 & 498 & 498 \\
\hline
\end{tabular}

Note: $\mathrm{DQ}=$ disclosure quality; $\mathrm{IA}=$ internal audit; $\mathrm{OWNCON}=$ ownership concentration; $\mathrm{CEOD}=\mathrm{CEO}$ duality; $\mathrm{BODIND}=$ board independence; BODS = board size; BODCI = board chairman independence; CHAIRTEN = chairman tenure; LEV = financial leverage; FSIZE $=$ firm size 


\subsection{Pearson Correlation}

To determine the level of the relationship among the variables, Pearson correlation coefficient has been used. Correlation coefficient is a statistical way to measure the level that a variable can be related to another variable linearly. The correlation coefficient should not be high among the variables of model. Gujarati (2003) argues that as a thumb of rule, correlation coefficient more than 0.8 is regarded as high correlation and hence indicates a serious problem of multicollinearity. Since the high correlation among the independent variables in a model, may lead to spoiling the results of regression. When the significance coefficient of a variable is less than $5 \%(\operatorname{sig}<5 \%), H_{0}$ will be rejected and $H_{1}$ will be cofirmed and significance of the two variables will be acceptable otherwise it will be unacceptable. As it is seen in the table, the level of correlation among the research variables indicates a significant correlation among the most of the variables, and therefore the results indicate that there is no multicollinearity between our variables.

Table 2. Pearson Correlation Matrix

\begin{tabular}{|c|c|c|c|c|c|c|c|c|c|c|}
\hline & $D Q$ & $I A U$ & OWNCON & $C E O D$ & $B O D I N D$ & $B O D S$ & $B O D C I$ & CHAIRTEN & $L E V$ & FSIZE \\
\hline$D Q$ & 1.00 & & & & & & & & & \\
\hline \multirow[t]{2}{*}{$I A U$} & & 1.00 & & & & & & & & \\
\hline & $0.29^{*}$ & & & & & & & & & \\
\hline \multirow[t]{2}{*}{ OWNCON } & & -0.12 & 1.00 & & & & & & & \\
\hline & $0.10^{*}$ & & & & & & & & & \\
\hline \multirow[t]{2}{*}{$C E O D$} & & $0.02 *$ & 0.02 & 1.00 & & & & & & \\
\hline & $0.32 *$ & & & & & & & & & \\
\hline \multirow[t]{2}{*}{ BODIND } & & $0.17^{*}$ & $0.14^{*}$ & $0.57^{*}$ & 1.00 & & & & & \\
\hline & $0.33^{*}$ & & & & & & & & & \\
\hline$B O D S$ & -0.02 & 0.00 & 0.04 & -0.07 & -0.02 & 1.00 & & & & \\
\hline \multirow[t]{2}{*}{$B O D C I$} & & 0.08 & $0.15^{*}$ & $0.65^{*}$ & $0.59^{*}$ & -0.04 & 1.00 & & & \\
\hline & $0.23 *$ & & & & & & & & & \\
\hline CHAIRTEN & 0.00 & -0.07 & $0.04 *$ & -0.08 & -0.03 & 0.09 & 0.00 & 1.00 & & \\
\hline \multirow[t]{2}{*}{$L E V$} & 0.03 & $-0.16^{*}$ & -0.03 & $0.16^{*}$ & $0.10^{*}$ & -0.04 & -0.04 & $0.10^{*}$ & & \\
\hline & & & & & & & & & 1.00 & \\
\hline \multirow[t]{2}{*}{ FSIZE } & -0.04 & -0.07 & $0.36^{*}$ & 0.06 & 0.08 & & $0.12 *$ & $-0.17^{*}$ & & 1.00 \\
\hline & & & & & & $0.21 *$ & & & 0.09 & \\
\hline
\end{tabular}

Note: DQ = disclosure quality; IAU = internal audit unit; OWNCON = ownership concentration; CEOD = CEO duality; BODIND = board independence; $\mathrm{BODS}=$ board size; $\mathrm{BODCI}=$ board chairman independence; $\mathrm{CHAIRTEN}=$ chairman tenure; $\mathrm{LEV}=$ leverage; FSIZE $=$ firm size

\subsection{Regression Results and Discussion}

According to the results of Hausman-test, the most suitable estimation method for all models is random effects. Therefore all models are run based on random effects estimation method. In model1, $(F=21.33)$ statistics, indicates the significance of regression modell that since $P$-Value $<5 \%$, and hence regression modell is significant. $R^{2}=29 \%$ also indicates the level of the relationship of the independent variables with disclosure quality (dependent variable). 
Internal audit unit independent variable is significant and indicates a positive and significant relationship between internal audit unit and disclosure quality as $15.91 \%$. Therefore, the first hypothesis is not rejected since our results support it. The control variables in this model are not significant as well. In model2, $(F=14.87)$ statistics, indicates the significance of regression model 2 that since $P$-Value $<5 \%$, regression model is significant. $R^{2}=22 \%$ also indicates the level of the relationship of the independent variables with disclosure quality (dependent variable). Ownership concentration independent variable is significant and indicates a positive and significant relationship between ownership concentration and disclosure quality as $20.13 \%$. Therefore, the second hypothesis is not rejected since our results support it. The size of the firm as control variable is significant as well and it is equal to -6.34 . In model3, $(F=18.30)$ statistics, indicates the significance of regression model3 that since $P$-Value $<5 \%$, regression model3 is significant. $R^{2}=26 \%$ also indicates the level of the relationship of the independent variables with disclosure quality (dependent variable). CEO duality as an independent variable is significant and indicates a positive and significant relationship between CEO duality and disclosure quality as $18.77 \%$. Therefore, the third hypothesis is not rejected since our results support it. The size of the firm as control variable is significant as well and it is equal to -2.36 . In model4, $(F=19)$ statistics, indicates the significance of regression model 4 that since $P$-Value $<5 \%$, regression model4 is significant. $R^{2}=27 \%$ also indicates the level of the relationship of the independent and control variables with disclosure quality (dependent variable). Board independence as an independent variable is significant and indicates a positive and significant relationship between board independence and disclosure quality as $30.29 \%$. Therefore, the fourth hypothesis is not rejected since our results support it. The size of the firm as control variable is significant as well and it is equal to -4.61 . In model5, $(F=13.52)$ statistics, indicates the significance of regression model5 that since $P$-Value $<5 \%$, regression model5 is significant. $R^{2}=21 \%$ also indicates the level of the relationship of the independent variables with disclosure quality (dependent variable). Board size as an independent variable is not significant ( $P$-Value $=$ 0.34). Therefore, fifth hypothesis is rejected because our result does not support it. The size of the firm as control variable is significant as well and it is equal to -4.41 . In model6, $(F=15.44)$ statistics, indicates the significance of regression model6 that since $P$-Value $<5 \%$, regression model6 is significant. $R^{2}=23 \%$ also indicates the level of the relationship of the independent variables with disclosure quality (dependent variable). Board chairman independence as an independent variable is significant and indicates a positive and significant relationship between board chairman independence and disclosure quality as $10.26 \%$. Therefore, the sixth hypothesis is not rejected since our results support it. The size of the firm as control variable is significant as well and it is equal to -4.7 . In model7, $(F=13.41)$ statistics, indicates the significance of regression model 7 that since $P$-Value $<5 \%$, regression model 7 is significant. $R^{2}=21 \%$ also indicates the level of the relationship of the independent variables with disclosure quality (dependent variable). The chairman tenure as an independent variable is not significant $(P$-Value $=0.6)$. Therefore, seventh hypothesis is rejected because our result does not support it. The size of the firm as control variable is significant as well and it is equal to -3.8 . 
Table 3. Multivariate Analysis

\begin{tabular}{|c|c|c|c|c|c|c|c|}
\hline Independent Variables & Model1 & Model2 & Model3 & Model4 & Model5 & Model6 & Model7 \\
\hline \multirow[t]{2}{*}{ Constant } & 56.33 & 77.07 & 61.12 & 60 & 66.02 & 69.55 & 71.63 \\
\hline & $(0.000)$ & $(0.000)$ & $(0.000)$ & $(0.000)$ & $(0.000)$ & $(0.000)$ & $(0.000)$ \\
\hline \multirow[t]{2}{*}{ Internal Audit } & $15.91 *$ & - & - & - & - & - & - \\
\hline & $(0.000)$ & - & - & & - & - & - \\
\hline \multirow[t]{2}{*}{ Concentration } & - & $20.13 *$ & - & - & - & - & - \\
\hline & & $(0.000)$ & & & & & \\
\hline \multirow[t]{2}{*}{ CEO Duality } & - & - & $18.77^{*}$ & - & - & - & - \\
\hline & & & $(0.000)$ & & & & \\
\hline \multirow[t]{2}{*}{ Board Independence } & - & - & - & $30.29^{*}$ & - & - & - \\
\hline & & & & $(0.000)$ & & & \\
\hline \multirow[t]{2}{*}{ Board size } & - & - & - & - & 1.81 & - & - \\
\hline & & & & & $(0.34)$ & & \\
\hline Chairman & - & - & - & - & - & $10.26^{*}$ & - \\
\hline Independence & & & & & & $(0.000)$ & \\
\hline \multirow[t]{2}{*}{ Chairman Tenure } & - & - & - & - & - & - & 0.16 \\
\hline & & & & & & & $(0.6)$ \\
\hline \multirow[t]{2}{*}{ Financial leverage } & 5.02 & 1.375 & -0.7 & -1.49 & 0.74 & 0.26 & 0.29 \\
\hline & $(0.2)$ & $(0.7)$ & $(0.47)$ & $(0.7)$ & $(0.8)$ & $(0.94)$ & $(0.9)$ \\
\hline \multirow[t]{2}{*}{ Firm Size } & -1.74 & $-6.34 *$ & $-2.36^{*}$ & $-4.61^{*}$ & $-4.41^{*}$ & $-4.7^{*}$ & $-3.8^{*}$ \\
\hline & $(0.08)$ & $(0.00)$ & $(0.01)$ & $(0.01)$ & $(0.02)$ & $(0.01)$ & $(0.04)$ \\
\hline \multirow[t]{2}{*}{$F$} & 21.33 & 14.87 & 18.30 & 19 & 13.52 & 15.44 & 13.41 \\
\hline & $(0.00)$ & $(0.00)$ & $(0.00)$ & $(0.00)$ & $(0.00)$ & $(0.00)$ & $(0.00)$ \\
\hline$R^{2}$ & $29 \%$ & $22 \%$ & $26 \%$ & $27 \%$ & $21 \%$ & $23 \%$ & $21 \%$ \\
\hline No of Observations & 498 & 498 & 498 & 498 & 498 & 498 & 498 \\
\hline
\end{tabular}

\section{Conclusion}

More and better disclosure of information is one of the effective and important characteristics and factors in investors' economic decisions and also one of the appropriate characteristics in competitive markets. The firms with stronger systems of corporate governance and appropriate monitoring may have more ability to impact on the firm management in order to disclose more and better information. The mentioned firms have the better qualitative indexes of the market and their stocks prices are less influenced by the deals and the possibility for dealing in these firms is at a low level based on confidential information, that is, the asymmetry of information is less and these firms lead to the efficiency of the capital market (Khoshbakht \& Mohammadzadeh Salteh, 2011). In this research, the association between corporate governance and disclosure quality has been investigated. Using a sample of 83 listed firms on Tehran Stocks Exchange (TSE) during period from 2005 to 2010, the results indicate that there is a significant and direct relationship between disclosure quality and explanatory variables such as internal audit, ownership concentration, CEO duality, board 
independence, and board chairman independence. However, our findings reveal that disclosure quality is not significantly associated with board size and chairman tenure of the board.

\section{Reference}

Aburaya, R. (2012). The Relationship Between Corporate Governance And Environmental Disclosure: UK Evidence. (Doctoral Thesis), Durham University. Available at Durham E-Theses Online: http://etheses.dur.ac.uk/3456/.

Akhtaruddin, M., Hossain, M. A., Hossain, M., \& Yao, L. (2009). Corporate governance and voluntary disclosure in corporate annual reports of Malaysian listed firms. Journal of Applied Management Accounting Research, 7(1), 1-19.

Babío Arcay, M. R., \& Muiño Vázquez, M. F. (2005). Corporate Characteristics, Governance Rules and the Extent of Voluntary Disclosure in Spain. Advances in Accounting, 21(0), 299-331. http://dx.doi.org/10.1016/S0882-6110(05)21013-1

Botosan, C. A. (1997). Disclosure Level and the Cost of Equity Capital. The Accounting Review, 72(3), 323-349. doi: 10.2307/248475

Cerbioni, F., \& Parbonetti, A. (2007). Exploring the Effects of Corporate Governance on Intellectual Capital Disclosure: An Analysis of European Biotechnology Companies. European Accounting Review, 791-826. http://dx.doi.org/10.1080/09638180701707011

Cheng, E. C. M., \& Courtenay, S. M. (2006). Board composition, regulatory regime and voluntary disclosure. The International Journal of Accounting, 41(3), 262-289. doi: http://dx.doi.org/10.1016/j.intacc.2006.07.001

Diamond, D. W., \& Verrecchia, R. E. (1991). Disclosure, Liquidity, and the Cost of Capital. $\begin{array}{llll}\text { The Journal } & \text { Finance, } & \text { 1325-1359. }\end{array}$ http://dx.doi.org/10.1111/j.1540-6261.1991.tb04620.x

Donnelly, R., \& Mulcahy, M. (2008). Board Structure, Ownership, and Voluntary Disclosure in Ireland. Corporate Governance: An International Review, 16(5), 416-429. http://dx.doi.org/10.1111/j.1467-8683.2008.00692.x

Graham, J. R., Koski, J. L., \& Loewenstein, U. (2006). Information flow and liquidity around anticipated and unanticipated dividend announcements. The Journal of Business, 79(5), 2301-2336. http://dx.doi.org/10.1086/505236

Gujarati, D. N. (2003). Basic Econometrics (4th ed.): McGraw-Hill/Irwin, International Edition.

Healy, P. M., Hutton, A. P., \& Palepu, K. G. (1999). Stock Performance and Intermediation Changes Surrounding Sustained Increases in Disclosure. Contemporary Accounting Research, 16(3), 485-520. http://dx.doi.org/10.1111/j.1911-3846.1999.tb00592.x 
Jalali, F. (2008). Corporate governance and accounting. Accountant Magazine (Accountant's Monthly), 23(196), 3-9.

Kanagaretnam, K., Lobo, G. J., \& Whalen, D. J. (2007). Does good corporate governance reduce information asymmetry around quarterly earnings announcements? Journal of $\begin{array}{llll}\text { Accounting } \text { and Public 26(4), } & \text { 497-522. }\end{array}$ http://dx.doi.org/10.1016/j.jaccpubpol.2007.05.003

Katmun, N. (2012). Disclosure quality determinants and consequences. (Doctoral Thesis), Durham University. Available at Durham E-Theses Online: http://etheses.dur.ac.uk/4930/.

Khodadadi, V., Khazami, S., \& Aflatooni, A. (2010). The effect of corporate governance structure on the extent of voluntary disclosure in Iran. Business Intelligence Journal, 3(2), 151-164.

Khoshbakht, H., \& Mohammadzadeh Salteh, H. (2011). Evaluating the relationship between corporate governance and voluntary disclosure in companies listed in Tehran stock exchange. Business and Management Review, 1(9), 23-33.

Klein, A. (1998). Firm Performance and Board Committee Structure The Journal of Law and Economics, 41(1), 275-304.

Lakhal, F. (2005). Voluntary earnings disclosures and corporate governance: evidence from France. Review of Accounting and Finance, 4(3), 64-85. http://dx.doi.org/10.1108/eb043431

Lang, M. H., \& Lundholm, R. J. (2000). Voluntary Disclosure and Equity Offerings: Reducing Information Asymmetry or Hyping the Stock? Contemporary Accounting Research, 17(4), 623-662. http://dx.doi.org/10.1506/9N45-F0JX-AXVW-LBWJ

Lev, B. (1992). Information disclosure strategy. California Management Review, 34(4), 9-32. http://dx.doi.org/10.2307/41166701

Nikoomaram, H., \& Badavar Nahandi, Y. (2009). Trasparancy and presenting the patterns to determine and evaluate the effective factors on financial reporting quality choice in Iran. Beyond Management, 2 (8), 141-187.

Sajadi, H., Zaranejad, M., \& Jafari, A. (2009). The effective non-financial characteristics on the quality of financial reporting on accepted corporates on Tehran Stocks Exchange. Iranian Accounting and Auditing Reviews, 16(57), 51-68.

Sengupta, P. (1998). Corporate Disclosure Quality and the Cost of Debt. The Accounting Review, 73(4), 459-474. doi: 10.2307/248186

Welker, M. (1995). Disclosure Policy, Information Asymmetry, and Liquidity in Equity Markets. Contemporary Accounting Research, 11(2), 801-827. http://dx.doi.org/10.1111/j.1911-3846.1995.tb00467.x 